\title{
PANDEMIAS, COLAPSO CLIMÁTICO, ANTIECOLOGISMO: EDUCAÇÃO AMBIENTAL ENTRE AS EMERGÊNCIAS DE UM ECOCÍDIO APOCALÍPTICO
}

Philippe Pomier Layrargues ${ }^{1}$

Num mundo que soçobra, só sobram sobras"

Arthur Soffiati (1990)

Resumo: $O$ presente ensaio pensa a Educação Ambiental a partir do nexo entre três crises imbricadas: o Antiecologismo, o Colapso Climático e a Pandemia. A conjuntura demarca um novo tempo histórico que desafia a Educação Ambiental a dialogar com esse quadro emergencial que tem como fundamento a necropolítica ecocida. O tempo presente cobra da Educação Ambiental a ressignificação de seus propósitos: apenas uma reformulação paradigmática que rompa com o conservadorismo pedagógico que deixou a Educação Ambiental subserviente ao interesse do Capital e instrumental ao Mercado, que forma cidadãos ecológicos passivos e conformados, poderá trazer respostas promissoras para a alteração desse quadro.

Palavras-Chave: Educação Ambiental; Pandemia; Colapso Climático; Ecocídio; Antiecologismo.

Abstract: The present essay thinks about Environmental Education from the nexus between three interwoven crises: Antiecologism, Climate Collapse and Pandemic. The conjuncture marks a new historic period that challenges Environmental Education to dialogue with this emergency situation that is based on ecocidal necropolitics. The present time demands Environmental Education to redefine its purposes: only a paradigmatic reformulation that breaks with the pedagogical conservatism that left Environmental Education subservient to the interest of Capital and instrumental to the Market, which forms passive and conformed ecological citizens, can bring promising answers to change this framework.

Keywords: Environmental Education; Pandemic; Climate Collapse; Ecocidal; Antiecologism.

1 Universidade de Brasília. E-mail: philippe.layrargues@gmail.com

revista brasileira 


\section{A teoria conspiratória do Comunavírus: um negócio que seria da China}

Se fôssemos adeptos da teoria conspiratória, acreditaríamos que o novo Coronavírus de 2020 foi resultado de uma invenção comunista chinesa elaborada para desestabilizar Trump e Bolsonaro, sabotar o capitalismo e então dominar triunfalmente o mundo. Pois é assim que pensa Jair Bolsonaro, o presidente do Brasil que segue à risca a cartilha do alinhamento ideológico subserviente aos Estados Unidos, pegando carona nas declarações insensatas de Donald Trump ${ }^{2,3}$ : todo o pandemônio dessa pandemia não passaria de um ardiloso plano de dominação global do Partido Comunista Chinês ${ }^{4}$ para implantar uma cruel ditadura no Ocidente ${ }^{5}$.

Ele não está sozinho. Seu filho, Eduardo Bolsonaro, ainda em março de 2020, na conjuntura diversionista para driblar a atenção da mídia que estava focada na cobertura dos panelaços em protesto contra seu pai por causa da sua postura irresponsável diante da pandemia, foi um dos primeiros no Brasil a repetir a acusação culpando a China como responsável pela pandemia ${ }^{6}$. 0 ministro das Relações Exteriores, Ernesto Araújo, fez coro à delirante teoria conspiratória, chamando publicamente o Coronavírus de "Comunavírus"7, por fazer despertar o 'pesadelo comunista' e sua ambição globalista ${ }^{8}$. Avesso ao multilateralismo, para ele, 'transferir' o poder da soberania nacional a uma instituição globalista como a Organização Mundial da Saúde (OMS) equivaleria dar um passo em direção ao comunismo.

Sim, com esta teoria conspiratória, a globalização, fenômeno demarcado pela abertura do livre-comércio global, subitamente se converteu num projeto sub-reptício de dominação comunista, onde a OMS seria a ponta de lança que subtrairia a soberania das nações em nome de uma suposta solidariedade global; mas que no fundo, com a criação de um estado permanente de exceção

\footnotetext{
2 https://www.bbc.com/portuguese/internacional-51966296

3 https://noticias.uol.com.br/colunas/tales-faria/2020/03/16/bolsonaro-esta-convencido-de-quecoronavirus-e-plano-do-governo-chines.htm

${ }^{4} \mathrm{Em}$ resposta à provocação, o Partido Comunista da China contra atacou, afirmando que o Coronavírus na verdade teria sido uma criação do exército norte-americano, e levado à China por um sargento que teria participado dos Jogos Mundiais Militares, em outubro de $2019 \mathrm{em}$ Wuhan, exatamente onde se registraram os primeiros casos de COVID-19.

(https://www.otempo.com.br/coronavirus/teoria-da-conspiracao-afirma-que-coronavirus-foicriado-pelo-exercito-dos-eua-1.2323334).

5 https://www.conjur.com.br/2020-jun-23/reis-friede-china-imperiomao?utm source $=$ dlvr.it\&utm medium $=$ facebook

${ }^{6}$ https://g1.globo.com/jornal-nacional/noticia/2020/03/19/eduardo-bolsonaro-culpa-china-porcoronavirus-e-gera-crise-diplomatica.ghtml

${ }^{7}$ https://www.metapoliticabrasil.com/post/chegou-o-comunav\%C3\%ADrus

8 https://oglobo.globo.com/mundo/covid-19-ernesto-araujo-denuncia-comunavirus-ataca-oms$\underline{24387155}$
}

Revbea, São Paulo, V. 15, № 4: 01-30, 2020. 
global transformando o mundo num grande campo de concentração, estaria empenhada apenas em vigiar e punir 9 .

Depois foi a vez do então ministro da Educação, Weintraub, polemizar ainda mais, insinuando em rede social ${ }^{10}$, que a China teria muito a ganhar em termos geopolíticos com a pandemia do Coronavírus: a China sairia da crise sanitária economicamente fortalecida, comprando petróleo e outras commodities a preços reduzidos e lucrando com a venda de equipamentos hospitalares, como os aparelhos respiradores. Um genuíno 'negócio da China'. Afinal, a China já havia conquistado bons resultados econômicos em períodos recentes de outras epidemias, e agora não seria diferente.

Porém, tudo indica que a realidade nega a teoria conspiratória. As projeções apontam que a tendência é de que haja uma queda no PIB chinês, pela primeira vez desde 1976. Isso porque a China agora é o principal exportador de mercadorias do mundo, e se os demais países estão com suas atividades econômicas suspensas, a China não vende sua produção. Além disso, o barateamento do preço do petróleo não se deveu exclusivamente à pandemia: a queda no valor do petróleo foi resultado de uma disputa geopolítica mal sucedida entre a Rússia e a Arábia Saudita, que resolveu unilateralmente aumentar a sua produção fazendo os preços despencarem. No limite, no mercado concorrencial global, as commodities tiveram seus valores rebaixados para todos, não apenas a China. Ou seja, uma crise econômica mundial não é necessariamente benéfica à China ${ }^{11}$, como ardilosamente tentam fazer crer os apóstolos da teoria conspiratória do Comunavírus.

Por outro lado, bem ao contrário do que afirma a teoria conspiratória do Comunavírus, quem parece estar saindo fortalecido economicamente da pandemia, são as cinco grandes empresas norte-americanas da indústria de tecnologia de comunicação: Apple, Amazon, Google, Facebook e Microsoft ${ }^{12}$. Sem aparecer nos holofotes, em plena pandemia conseguiram ostentar uma saúde financeira invejáve $\left.\right|^{13}$, expandindo globalmente seus negócios para áreas estratégicas como educação, defesa e saúde. Na área da saúde, por sinal, a pandemia representou um vigoroso estímulo nos negócios dessas empresas que ampliaram-se na direção da telemedicina e dos aplicativos de

\footnotetext{
${ }^{9}$ https://g1.globo.com/jornal-nacional/noticia/2020/04/22/ministro-das-relacoes-exterioresafirma-que-coronavirus-e-um-plano-comunista.ghtml

https://www.correiobraziliense.com.br/app/noticia/politica/2020/04/04/interna politica,842431/w eintraub-usa-cebolinha-da-turma-da-monica-para-atacar-a-china.shtml

11 https://economia.uol.com.br/noticias/redacao/2020/03/19/impactos-economicos-coronaviruschina.htm

12 https://veja.abril.com.br/tecnologia/na-crise-gigantes-como-apple-google-e-facebookexpandem-atuacao/

${ }^{13}$ https://www.uol.com.br/tilt/noticias/redacao/2020/05/20/se-deram-bem-como-ficam-as-bigtecs-durante-a-crise-do-coronavirus.htm
} 
rastreamento do vírus ${ }^{14}$. Essas "Big Five", gigantes da computação, expandiram seus negócios como um vírus: o Google Classroom por exemplo, ampliou seu número de usuários de 50 milhões para cem milhões em apenas dois meses, de março a abril de 2020.

Como todo projeto de poder da extrema direita fascista, é fundamental para sua existência a criação de inimigos permanentes a combater e eliminar. A narrativa ideológica do Comunavírus criou o 'bode expiatório' que passou a unificar a coesão social da base de sustentação bolsonarista no poder ${ }^{15}$. $O$ ódio ao PT, bem como ao comunismo e à esquerda, convergiu em ódio ao 'vírus chinês', nomenclatura maniqueísta que costuma circular entre bolsonaristas, justamente para tentar estabelecer essa espúria correlação de um vírus como uma fraude comunista para manipular a economia global.

Instalada no centro do poder executivo federal, a teoria conspiratória do vírus chinês se encontra com o negacionismo científico também tão basilar na cultura política da extrema direita. O receituário da OMS e de lideranças epidemiológicas para o combate ao novo Coronavírus, que consiste basicamente no isolamento social, é sistematicamente rejeitado pelo círculo bolsonarista, que despeja toda ira contra as autoridades que adotam as estratégias de contenção da pandemia recomendadas pela OMS, fazendo prevalecer entre os apoiadores de Bolsonaro a negação do poder de contágio e da letalidade do vírus ${ }^{16}$.

É neste desconcertante cenário que mescla uma teoria conspiratória com o negacionismo científico, que a cruzada bolsonarista contrária à quarentena como opção para 'salvar' a economia do desastre, ganha a sustentação argumentativa. A perda de empregos e a crise econômica advinda das medidas de quarentena eram apenas uma cortina de fumaça que encobria a real motivação da tal 'briga' entre economia e saúde com suas idas e vindas no relaxamento do isolamento social e flexibilização na reabertura do comércio e serviços não essenciais. Com Bolsonaro no poder, o Brasil definitivamente não seria vítima do projeto comunista chinês de sabotar o capitalismo. Aqui a economia não seria travada só por causa de uma 'gripezinha'. O isolamento social aludido como o único remédio para combater a pandemia não seria aceito como o pretexto comunista para derrubar a economia (capitalista).

E assim, pretendendo preservar não a vida das pessoas, mas a vitalidade da atividade econômica (capitalista), o projeto bolsonarista se destaca gloriosamente como a vanguarda mundial da luta anticomunista, e o Mito desponta como um iluminado líder capaz tanto de desmascarar o plano

\footnotetext{
14 https://revistapegn.globo.com/Tecnologia/noticia/2020/05/google-e-apple-criaram-tecnologiapara-rastrear-o-coronavirus-agora-precisam-convencer-pessoas-usa-la.html

15 http://www.observatoriodaimprensa.com.br/conjuntura-politica/bolsonarismo-e-o-viruscomunistal

${ }^{16} \mathrm{https}: / /$ epoca.globo.com/brasil/isolamento-coisa-de-comunista-os-zaps-bolsonaristas-durantepandemia-1-24347242
} 
macabro chinês de dominação mundial, como de afrontar o comunismo: colocando como prioridade do governo a reabertura das atividades econômicas antes mesmo do país ter alcançado o pico de contaminação pelo Coronavírus, e disseminando a cultura do ódio contra a China comunista a partir de seus aparelhos ideológicos de Estado. Argumentando que a crise econômica resultaria em muito mais mortes do que a própria pandemia já causaria, a mensagem ideológica bolsonarista fica clara: quando as pessoas perderem seus empregos e ficarem sem renda, não venham culpar o presidente; e sim os comunistas que tentaram sabotar o capitalismo recorrendo ao ardiloso plano de paralização mundial da economia.

Nesta ideologia ultra neoliberal e anticomunista, não há ausência de Estado, ao contrário; o Estado está presente e atuante, instalando a cizânia e fazendo balbúrdia para sabotar a política de enfrentamento da pandemia de cabo a rabo: desde a negação dos fatos e censura de informações, passando pela desobediência das recomendações cientificamente validadas, culminando no brutal e proposital desamparo dos mais vulneráveis que dependeriam de um auxílio econômico emergencial que jamais encontrou seu destino, o que forçou a classe trabalhadora ter que escolher entre morrer doente ou de fome, e se tornar a ponta de lança do mercado para reativar a roda da economia (capitalista). Porque não poderia contar com qualquer apoio do governo, que por sinal, foi eleito para o 'laissez-faire'.

A geopolítica da nova guerra fria entre EUA e China contaminou as entranhas da crise de saúde pública mundial17, 18, 19. A dimensão geopolítica se entrelaçou profundamente com a política de combate ao Coronavírus, trazendo a gestão da COVID-19 para o terreno da batalha ideológica da nova guerra fria, o que evidentemente, dificultou a governabilidade multilateral da crise global que exigiu antes de tudo, solidariedade.

No âmbito das relações internacionais, o Brasil abandonou a postura clássica de país mediador de conflitos para se posicionar ostensivamente no tabuleiro do jogo, mas submisso aos EUA. A crise diplomática que o governo brasileiro gerou em relação à China - o principal parceiro comercial brasileiro que representa um quarto da balança comercial ${ }^{20}$ e um dos poucos países capazes de produzir fármacos e equipamentos hospitalares para cuidar dos pacientes da COVID-19 - acusando-a de culpada pela pandemia, é a face que mostra claramente como o interesse ideológico perigosamente se sobrepôs ao genuíno interesse nacional. A gratuidade em ameaçar a principal parceria

\footnotetext{
17 https://jornaldebrasilia.com.br/mundo/eua-e-china-trocam-acusacoes-sobre-origem-dapandemia-de-coronavirus/

18 https://noticias.uol.com.br/ultimas-noticias/afp/2020/05/24/china-alerta-para-nova-guerra-friacom-os-eua-por-pandemia-que-assola-a-america-latina.htm

${ }^{19} \mathrm{https}$ ://brasil.elpais.com/internacional/2020-06-27/antonio-guterres-relacao-disfuncional-entreeua-china-e-russia-impede-resposta-comum-a-pandemia.html

20 https://brasil.elpais.com/brasil/2020-03-19/esforco-de-eduardo-bolsonaro-para-demonizarchina-copia-trump-e-ameaca-elo-estrategico-do-brasil.html
} 
econômica internacional responsável pela vitalidade da economia brasileira, contradiz frontalmente 0 argumento de manter ativa a economia mesmo durante a pandemia para salvá-la da crise decorrente do Comunavírus. Se havia de fato interesse em preservar a economia brasileira do colapso, não se comprometeria os negócios comerciais entre Brasil e China.

$\mathrm{E}$ neste contexto, ingressando na inconsequente cruzada imaginária contra o comunismo, o Brasil se tornou um dos raros e insanos exemplos de como a grave crise sanitária da pandemia foi manipulada politicamente e ficou completamente sem controle, por ter sofrido uma apropriação ideológica das mais absurdas possível. Na contramão das recomendações da OMS, resultou na inimaginável implantação da necropolítica na população brasileira, uma vez que a omissão governamental em estimular a política do isolamento social para salvar vidas por meio da redução da taxa de contaminação, corresponde à aplicação da 'imunidade de rebanho' natural, advinda com a exposição em massa da população ao vírus, quando vai desprotegida às compras. Às custas de muitas vidas perdidas, o que representaria uma tragédia humanitária ${ }^{21}$.

Não é mera coincidência que justamente os dois países com governos negacionistas e adeptos da teoria conspiratória do vírus chinês tenham sido os epicentros de maior proporção de contaminação por COVID-19 no planeta ${ }^{22}$. Fizeram a delirante opção pela defesa da vitalidade do mercado, e não pela defesa da vida humana. A necropolítica é sua marca registrada. Se agora não fica claro que a ideologia capitalista considera o capital acima de tudo e o deus mercado acima de todos e sacrifica vidas humanas em seu nome, quando será?

Mas... E daí? Todo mundo morre um dia, não é?

\section{A degradação ambiental está na natureza da pandemia}

O vírus não veio de um laboratório. Veio da natureza mesmo. Precisamente, de animais selvagens; e muito provavelmente, vendidos no popular Mercado Atacadista de Frutos do Mar de Wuhan, na China. Só que além de pescados, dentro do mercado se comercializa mais de cem espécies animais, alguns vivos, outros abatidos, e tudo em condições insalubres; como raposas, crocodilos, cobras, ratos, morcegos, pavões, porcos-espinho, cervos e até avestruzes ${ }^{23}$.

21 https://www.cartacapital.com.br/saude/apos-ultrapassar-um-milhao-de-casos-de-covid-19especialista-alerta-fim-da-quarentena-piorara-o-quadro-no-brasil/

22 https://www.correiocidadania.com.br/2-uncategorised/14253-diario-da-covid-19-brasil-nafrente-dos-eua-nos-numeros-diarios-da-pandemia

${ }^{23}$ https://epoca.globo.com/sociedade/marco-zero-de-coronavirus-pode-ser-mercado-quevendia-cobras-ratos-24205185 
Assim como a origem de muitas epidemias, o novo Coronavírus não foi 'fabricado' em um laboratório chinês de biossegurança ${ }^{24,25}$, no contexto de uma guerra biológica 26,27 , como nos faz supor essa derivação da teoria conspiratória do Comunavírus. As análises genéticas do novo Coronavírus evidenciaram que pela sua complexidade, não seria possível tecnologicamente cria-lo em laboratório; e que sua característica genética se assemelha ao vírus da Síndrome Aguda Respiratória Grave (SARS), que tem no morcego seu hospedeiro original. Trata-se enfim, de uma zoonose. Como muitas outras.

O vírus até poderia ter sido fabricado em algum laboratório de biossegurança e engenharia genética, no contexto de uma eventual guerra biológica; mas acreditamos ser mais realista confiar na hipótese de que o vírus seja uma existência da natureza em desequilíbrio, do que acreditar na desequilibrada teoria conspiratória. Porque essa teoria conspiratória de que o vírus seja uma arma biológica tecnologicamente manipulada, compreende a uma realidade muito particular, informando que a pandemia seja resultante de uma disputa geopolítica entre duas potências econômicas envolvendo o controle da economia mundial; argumento que não permite que se ponha em evidência a possibilidade da pandemia ser um complexo fenômeno decorrente de processos de exploração econômica abusiva da natureza, que culminaram na derradeira degradação ambiental capaz de resultar numa perigosa zoonose como consequência do desequilíbrio ecológico atingido. Por isso é importante desmontar e desmentir as teorias conspiratórias e seu falseamento ideológico da realidade. Afirmar que é tudo fruto da conspiração imperialista comunista de dominação global é colocar uma cortina de fumaça de dimensões amazônicas para ocultar a localização das origens da pandemia de onde ela provavelmente emergiu, fazendo crer que tudo se resolveria dentro de laboratórios de bioengenharia e biossegurança, de onde supostamente teria surgido. Ou seja, nessa perspectiva, dificilmente vingaria a possibilidade de se correlacionar 0 presente surto pandêmico da COVID-19 com os processos de degradação ambiental por qual sofre agudamente grande parte dos ecossistemas florestais no planeta. Essa relação causal, portanto, permanece convenientemente ocultada.

Para as ciências ecológicas, o fenômeno da zoonose já é conhecido de longa data. Micróbios ou vírus podem 'saltar' de uma espécie hospedeira para outra. Conseguindo se adaptar, ganha um novo hospedeiro, o que permite então ampliar suas chances de perpetuação biológica, já que seu potencial biótico foi magnificado. O termo técnico desse processo se chama "Spillover", que pode ser traduzido como 'transbordamento'. O que parece garantir a

\footnotetext{
${ }^{24}$ https://noticias.uol.com.br/confere/ultimas-noticias/2020/03/30/coronavirus-nao-foi-criado-emlaboratorio-pelo-partido-comunista-da-china.htm

$25 \mathrm{https}: / /$ www.bbc.com/portuguese/geral-52506223

$26 \mathrm{https}$ ://istoe.com.br/eua-investigam-se-coronavirus-foi-criado-pela-china-diz-tv/

27 https://canaltech.com.br/saude/coronavirus-arma-biologica-a-ciencia-mostra-que-nao$\underline{162050 /}$
} 
adaptabilidade a um novo hospedeiro após o transbordamento de espécies, é a fácil mutabilidade genética de um vírus ${ }^{28}$. Zoonoses são doenças que antes eram exclusivas de animais não humanos, que por causa do transbordamento, acabaram se tornando doenças também humanas. As zoonoses representam nada menos que cerca de $60 \%$ das doenças infecciosas em humanos.

O Hantavírus é proveniente de roedores. O vírus da febre amarela é proveniente de macacos. A Gripe Aviária H5N1 é proveniente de aves silvestres e a Gripe Suína H1N1 é proveniente de porcos. O Sarampo provavelmente vem de cabras. O HIV-1 é proveniente de chimpanzés. A SARS é proveniente do gato-da-algália. A Síndrome Respiratória do Oriente Médio (MERS) é proveniente do dromedário. O Zika é proveniente do famoso mosquito Aedes aegypti. O novo Coronavírus é proveniente do morcego...

Isso não é coisa de laboratórios secretos que produzem armas biológicas, é mesmo coisa do mundo natural. Mas do mundo natural ecologicamente desequilibrado: o surto de Ebola de 2013 na África Ocidental é resultado de significativas perdas florestais devido à agricultura industrial que levou a vida selvagem a circular por fragmentos florestais empobrecidos e então se aproximar dos assentamentos humanos; a gripe aviária está relacionada à criação intensiva de aves e o vírus Nipah por exemplo, surgiu devido à intensificação da suinocultura e à produção de frutas na Malásia, tendo como detonação do surto, incêndios florestais em massa.

Os morcegos parecem ser animais especialmente suscetíveis de serem 'doadores' de vírus. Afinal, existe uma grande diversidade de espécies desse mamífero voador que vive aglomerado em grandes colônias, cujos habitats naturais vêm sendo sistematicamente destruídos forçando-os a procurar abrigo e alimento em áreas antropizadas. E a lista é longa: vírus Hendra, Marlburg, Nipah, Raiva, Ebola, SARS que por sinal também é originada por um Coronavírus... Assim, à primeira vista, precipitadamente diagnosticada como a causa da pandemia do novo Coronavírus, a tendência natural para eliminar zoonoses, seria combater o próprio morcego, para extinguir também suas doenças. A questão é que o problema não é exatamente o morcego, mas seu habitat: invadido pela expansão dos assentamentos humanos, fragmentado e degradado pela expansão da prática agropecuária. Ademais, seria trágico eliminar os morcegos, seres vivos que cumprem um valioso papel de prestação de dois importantes serviços ambientais enquanto simplesmente se alimentam: a dispersão de sementes e o controle de insetos.

A expansão do consumo de produtos de origem animal selvagem crua ou mal cozida de zonas rurais para periurbanas, onde existem mercados populares que misturam para comercialização animais domésticos e silvestres vivos em péssimas condições de salubridade, é considerado um vetor de zoonoses, e está na origem da atual pandemia. O mercado de Wuhan,

28 https://saude.abril.com.br/medicina/coronavirus-pandemia-zoonose/ 
epicentro do surgimento do Coronavírus, se caracteriza exatamente por esses fatores, onde o morcego e o pangolim (personagens principais desse drama sanitário, entre outros animais amontoados como mercadorias vivas sob forte estresse), ocupam promiscuamente o mesmo espaço com o ser humano. Essa é a conjuntura ideal do transbordamento de um vírus ${ }^{29}$.

Aliás, especialistas suspeitam inclusive que, repetindo o padrão de origem da COVID-19, por estabelecer essa ponte necessária ao transbordamento, as futuras pandemias podem surgir derivadas do consumo de carne de animais selvagens. Não só porque há um aumento na demanda local do consumo de carne de animais selvagens pela nova classe média chinesa - demanda que se dá em função da crença cultural asiática apostar nas vantagens nutricionais dos animais selvagens caçados em relação aos rebanhos domesticados -; há também um comércio internacional ilegal de carne de animais selvagens contrabandeada ${ }^{30}$, cuja demanda responde pela busca gourmet de sabores exóticos. A alfândega dos aeroportos de Paris confisca sete toneladas de carne de animais selvagens anualmente. Estima-se que, sem contar com os países asiáticos, de dois a treze milhões de toneladas de carne de animais selvagens são consumidas anualmente. $O$ próprio pangolim, o animal mais caçado do mundo e que foi o estopim do novo Coronavírus, cujo consumo é proibido na União Europeia, pode ser encontrado ilegalmente em alguns restaurantes franceses ${ }^{31}$.

Além do consumo de carne de animais selvagens, em termos causais das epidemias recentes, a degradação ambiental está na raiz do problema ${ }^{32,33}$. A qualidade ambiental severamente comprometida está no DNA de origem das epidemias. Onde surgiu o foco inicial das últimas epidemias, foi justamente onde áreas naturais sofreram forte desequilíbrio ecológico, combinado com o aumento da proximidade de rebanhos domésticos com os animais selvagens vitimados por seus habitats invadidos e devastados frente à expansão agropecuária. $\mathrm{O}$ empobrecimento da biodiversidade como consequência do desmatamento de florestas nativas, causado pelo avanço predatório da fronteira agropecuária, acarreta na debilitação da saúde dos animais silvestres que passam a sobreviver sob severas pressões ambientais.

A degradação ambiental compromete o Serviço Ecossistêmico provido por biomas com alta biodiversidade e ecologicamente íntegros (DAILY, 1997; NAYLOR e EHRLICH, 1997). A diversidade biológica representa uma barreira de proteção natural, que por diluição, amortiza o transbordamento; na medida

\footnotetext{
${ }^{29}$ https://www.conjur.com.br/2020-mar-28/ambiente-juridico-relacao-entre-meio-ambientepandemia-coronavirus

$30 \mathrm{https}: / /$ zap.aeiou.pt/carne-animais-selvagens-proxima-pandemia-325172

31 https://www.francetvinfo.fr/sante/alimentation/document-enquete-sur-le-trafic-de-viande-debrousse 3824973.html

32 https://www.elmostrador.cl/cultura/2020/05/27/la-destruccion-de-la-naturaleza-y-su-vinculocon-el-coronovirus/

33 https://revistapesquisa.fapesp.br/da-floresta-para-as-cidades/
} 
que os muitos hospedeiros naturais abrigam os vírus. Contudo, como consequência da degradação ambiental, a barreira natural de proteção contra zoonoses é quebrada quando ocorre o empobrecimento da biodiversidade; e de fato, estudos recentes indicam que as doenças transmitidas de animais selvagens para seres humanos estão em plena ascensão à medida que habitats naturais são destruídos ${ }^{34}$.

É o panorama diagnosticado pelo Programa das Nações Unidas para o Meio Ambiente (PNUMA), no início de março de 2020, que finalmente trouxe luz à reflexão sobre as causas primeiras da pandemia do novo Coronavírus, vinculadas a fatores ambientais, e não geopolíticos. À medida que habitats selvagens são dizimados, verifica-se um aumento equivalente no surgimento de zoonoses. Estudos sugerem que habitats ecologicamente comprometidos podem provocar processos evolutivos mais rápidos nos vírus, favorecendo sua diversificação ${ }^{35}$.

A bem da verdade, o próprio PNUMA já havia elaborado um relatório (UNEP, 2016) estabelecendo os nexos - evidentes mas dramaticamente negligenciados - entre ambientes naturais crescentemente degradados e 0 surgimento sem precedentes de zoonoses com potencial pandêmico. Evidências científicas comprovam que epidemias e pandemias são reflexo inquestionável da degradação ambiental. A entidade sublinhou a estreita relação entre ambientais saudáveis e pessoas saudáveis, e tratou o assunto como uma "questão emergente de preocupação ambiental", chamando a atenção para a possibilidade de aumento de recorrência e letalidade de pandemias em função do adiantado estado de degradação ambiental global no qual se encontra a biosfera. Destacamos ainda o duplo entendimento que podemos compreender dessa 'emergência', sinalizando ao mesmo tempo para os sentidos de surgimento e de urgência: uma perigosa novidade que emerge, que em si representa uma vulnerabilidade urgente a se preocupar.

Também no auge da pandemia, a organização não governamental Wildlife Conservation Society publicou um relatório (EVANS et al, 2020) assinalando o desequilíbrio ecossistêmico como o contexto de origem das zoonoses em geral e da pandemia do novo Coronavírus em particular.

O estudo de Contini et al (2020) vai na mesma direção, apontando que a origem do COVID-19 se encontra na degradação ambiental, frisando que o transbordamento do novo Coronavírus só pôde ter acontecido em função de práticas produtivas no campo ecologicamente danosas.

Em reportagem, a célebre primatologista Jane Goodall corrobora o fato da destruição dos habitats naturais forçar os animais selvagens a migrar, com sua saúde fragilizada e imunidade comprometida, para regiões cada vez mais

\footnotetext{
${ }^{34}$ http://www.ihu.unisinos.br/597375-o-coronavirus-nos-obriga-a-reconsiderar-a-biodiversidadee-seu-papel-protetor

35 https://www.unenvironment.org/pt-br/noticias-e-reportagens/reportagem/surto-de-coronaviruse-reflexo-da-degradacao-ambiental-afirma
} 
próximas dos assentamentos humanos, resultando no aumento do contato entre animais selvagens e domésticos, e com o próprio humano, potencializando o surgimento de zoonoses ${ }^{36}$.

Pedro Dallari, professor do Instituto de Relações Internacionais da USP é categórico ao acrescentar que a destruição ambiental causadora das epidemias avança a passos largos silenciosamente, sem levantar suspeitas e sem despertar a mesma reação de combate ao novo Coronavírus focado obstinadamente na mitigação das consequências sociais e econômicas ${ }^{37}$.

É neste cenário que Marc Dourojeanni, professor da Universidade Nacional Agrária de Lima (Peru), lembra que enquanto não cessar a fonte da degradação ambiental, o risco de aparecimento de novos vírus está sempre presente ${ }^{38}$; lembrando-nos da insistente permanência da Sociedade de Risco.

Allan Carlos Pscheidt, professor das Faculdades Metropolitanas Unidas, de São Paulo, é outro cientista que endossa a correlação entre a degradação ambiental e a emergência do novo Coronavírus. O autor acrescenta ainda que é vital que os cidadãos cobrem dos governos que interfiram nas causas que originam pandemias, ou seja, que adotem a proteção ambiental como meio prioritário de enfrentamento da COVID-1939.

O editor ambiental do The Guardian, Damien Carrington, assinou reportagem que correlaciona a pandemia como resultado direto da degradação ambiental, frisando que a destruição das florestas, o comércio ilegal de animais selvagens e o modelo de produção animal industrializada são as forças motrizes geradoras dessa pandemia ${ }^{40}$.

Em entrevista, Rob Wallace (2020), autor de Pandemia e Agronegócio, vai mais longe na responsabilização das causas da pandemia do que simplesmente dizer que é a 'degradação ambiental' genericamente apontada, e declara que o aumento das ocorrências de epidemias e pandemias virais nas últimas décadas está diretamente correlacionado ao modelo mundial de produção agroalimentar das grandes corporações do agronegócio capitalintensivo, notadamente a produção animal industrializada, que visa mais à

${ }^{36} \mathrm{https}: / /$ www.anda.jor.br/2020/04/nosso-desrespeito-pelos-animais-causou-esta-pandemia-dizprimatologista/?fbclid=IwAROKngeMh7Z9B7y7oZ6RAdICgltMZEHqaYga oQJbjhrXatayZ9ZhDqZul

${ }^{37} \mathrm{https}$ ://jornal.usp.br/radio-usp/coronavirus-e-crise-ambiental-deixam-a-saude-do-planeta-emriscol

$38 \mathrm{https}$ ://www.oeco.org.br/colunas/marc-dourojeanni/coronavirus-uma-interpretacao-ecologica/

39 https://www.brasildefato.com.br/2020/03/18/acao-humana-contra-o-meio-ambiente-causou-apandemia-do-coronavirus-diz-pesquisador

${ }^{40} \mathrm{https}$ ://amp.theguardian.com/world/2020/jun/17/pandemics-destruction-nature-un-wholegislation-trade-green-

recovery? twitter impression=true\&fbclid=IwAR25rMi2HrwmHaBXyi2mQ17-

Y52gMyXVaMD57Pk0s9g8MTTSwMfpd8IcarA

Revbea, São Paulo, V. 15, № 4: 01-30, 2020.

revista brasileira

educação ambiental 
reprodução do capital do que propriamente a oferta de alimento ${ }^{41}$. No limite, é o plano de negócios que sustenta a lógica produtiva agroindustrial capitalintensivo, que está na essência da degradação ambiental que se verifica disseminada na escala global. $O$ autor frisa ainda que ante os novos surtos epidêmicos, governos, sistemas de saúde e a mídia se concentraram tanto nas consequências da emergência sanitária que desprezaram a causa estrutural responsável pelos surtos, impedindo-se que se interfira nela.

Larissa Mies Bombardi, professora da Universidade de São Paulo e autora do Atlas Geografia do Uso de Agrotóxicos no Brasil, também em entrevista ${ }^{42}$ explicando 0 argumento central da tese de Wallace, acrescenta 0 argumento que toda essa alta tecnologia dessa força produtiva poderosa que é o agronegócio, foi capaz tanto de eliminar o mecanismo natural que fornece o serviço ecossistêmico de saúde ambiental que mantinha o equilíbrio ecológico dos microrganismos, como de promover o transbordamento desses patógenos para animais confinados e com sistema imunitário depressivo. A proteção natural foi rompida e esse Serviço Ecossistêmico essencial foi interrompido, literalmente, por um sistema produtivo que promove a doença. A professora conclui afirmando que é importantíssimo compreender que estar diante de uma pandemia está relacionado ao modo que a agricultura em escala global foi estruturada: fundamentalmente a partir da obtenção do lucro, e que é isso que deve estar em questão.

É importante ficar claro que a produção de três commodities - a carne, o óleo de palma e a soja -, frequentemente estão vinculados à degradação ambiental equivalente a um verdadeiro ecocídio em seus territórios. Se por um lado a cultura do 'Agro é Pop' ostenta com orgulho o título de ser o setor produtivo que sustenta a economia, por outro lado é responsável pelo rompimento desse Serviço Ecossistêmico prestado gratuitamente pela natureza que provê saúde ambiental: é uma face da 'produção destrutiva' (MÉSZÁROS, 1989) em favor da reprodução do capital em larga escala, é a lógica da economia de mercado no controle do agronegócio. A supressão da segurança ecológica de uma natureza saudável apenas para deixar a boiada passar é um custo muito alto para esse setor da economia bancar o discurso de ser responsável pela 'salvação da lavoura'. Desse modo, não será apenas a vaca que vai para o brejo.

$\mathrm{Na}$ mesma direção de acusar o modelo de produção animal industrializada como sendo a determinação primeira da degradação ambiental, Michael Greger, médico especialista em doenças infecciosas e defensor da dieta vegetariana, sob a justificativa do vegetarianismo contribuir com a prevenção de doenças; argumenta que há uma boa probabilidade de que o

41 https://editoraelefante.com.br/de-onde-veio-o-coronavirus-e-por-que-se-

espalhou/?ct=t\%28PANDEMIA+compilado+textos+blog\%29\&mc cid=3eb6bcf5f1\&mc eid=\%5 BUNIQID\%5D

42 https://www.redebrasilatual.com.br/ambiente/2020/04/coronavirus-agronegocio-modelopredatorio/ 
próximo Coronavírus venha de porcos e não de pangolins, em função da vertiginosa expansão dos complexos industriais de criação de suínos mundo afora e particularmente na China ${ }^{43}$. Com efeito, no início de março de 2020 a China detectou na província de Hubei - onde se localiza a cidade de Wuhan javalis contaminados pelo vírus da peste suína africana ${ }^{44}$; e três meses depois, ainda no transcurso da pandemia do novo Coronavírus, foi descoberta na China uma nova linhagem do vírus Influenza com potencial pandêmico. Essa linhagem tem porcos como hospedeiros e pode infectar humanos ${ }^{45}$.

Causa surpresa e indignação, nesse contexto, ver que no momento da pandemia, tenha sido proposto um Projeto de Lei que altera a definição conceitual da Reserva Extrativista, para com esse artifício, permitir a criação de animais de grande porte nessas Unidades de Conservação no Brasil, até então proibida por lei ${ }^{46}$. A criação de rebanhos nestes ambientes equivale nada menos do que a construção de pontes perfeitas para o transbordamento dos vírus. Autor da proposta, o deputado Júnior Ferrari (PSD/PA), parece ignorar completamente o risco sanitário da produção de rebanhos nas Reservas Extrativistas, via de regra, definidas como áreas naturais protegidas e em boas condições ecológicas, mas ameaçadas.

A conexão entre vida silvestre e doenças não é nova ${ }^{47}$. Essa pandemia do novo Coronavírus não surpreendeu os especialistas, porque era previsível. Não faltaram diagnósticos científicos fazendo alusão aos riscos de perigosas pandemias por zoonoses associadas ao desmatamento de florestas nativas em favor do agronegócio capital-intensivo, o que faltou foi planejamento governamental para uma situação de emergência. Os especialistas não se perguntavam se poderia acontecer alguma pandemia particularmente ameaçadora, mas sim quando ela aconteceria. A correlação entre degradação ambiental e pandemias virais está devidamente estabelecida, cientificamente validada. Era só uma questão de tempo até surgir uma pandemia que seria um divisor de águas demarcando o atingimento de uma situação-limite capaz de provocar uma trágica interrupção no cotidiano do planeta humano.

Assim como muitos virologistas e epidemiologistas familiarizados com o diagnóstico da recorrência crescente das zoonoses, o escritor especializado em divulgação científica David Quammen (2012), no livro Spillover, indagou se o novo Coronavírus seria o 'The Next Big One', o derradeiro e temido vírus com potencial de derrubar a humanidade. Entre as incertezas, uma coisa parece

\footnotetext{
${ }^{43}$ https://www.anda.jor.br/2020/05/o-proximo-coronavirus-pode-vir-de-porcos-e-nao-depangolins-diz-especialista/

${ }^{44}$ https://opresenterural.com.br/china-registra-novo-caso-de-peste-suina-africana-em-javali-naprovincia-de-hubei/

45 https://noticias.uol.com.br/ultimas-noticias/bbc/2020/06/29/novo-virus-da-gripe-com-potencialpandemico-e-descoberto-na-china.htm

${ }^{46} \mathrm{https}$ ://www.camara.leg.br/noticias/643485-projeto-permite-a-criacao-de-rebanhos-de-grandeporte-em-reservas-extrativistas/?fbclid=IwAR0H2vDkOKjGf8zy479JaevHObYCnIZqGVm5 1LO3mwQQpJN2yiK6NIHuM

47 https://www.cartamaior.com.br/?/Editoria/Mae-Terra/Pandemia-e-o-meio-ambiente/3/47892
}

Revbea, São Paulo, V. 15, № 4: 01-30, 2020.

revista brasileira

educação ambiental 
certa ao autor: depois dessa crise que paralisou o mundo, haverá outra. Porque se deu mais importância às consequências do que as causas da pandemia, desprezando-se, portanto, as aprendizagens sobre como não insistir no mesmo erro sem mudar o que seria preciso mudar. Essa crise precisaria ter ser encarada como uma lição para o futuro, declara o escritor.

Carlos Zambrana-Torrelio, vice-presidente de Conservação e Saúde da organização não-governamental EcoHealth Alliance, assevera que a taxa de desmatamento de uma determinada área representaria o indicador mais importante na determinação de onde uma próxima pandemia pode surgir. Seguir invadindo e destruindo habitats selvagens é ter certeza de que novas doenças virais mortais seguirão surgindo no futuro. Portanto, assegura Carlos Zambrana-Torrelio, se realmente quisermos interromper o ciclo de pandemias, é fundamental interromper o desmatamento ${ }^{48}$.

Por ser a fonte de origem da pandemia, a contenção imediata do desmatamento e a revitalização da biodiversidade e das condições ecológicas das áreas degradadas é a única forma de minimizar ou controlar as causas do surgimento de futuras pandemias.

É importante notar que a localização geográfica da origem do novo Coronavírus foi descrita com muita precisão pela mídia (apesar de persistirem controvérsias ${ }^{49}$ ): o 'marco zero' onde tudo começou foi no mercado popular de Wuhan na China. Ali foi identificado com muita assertividade o epicentro da pandemia. Mas essa é uma meia-verdade, porque "onde tudo começou" é um pouco antes do vírus ter entrado no mercado. O contexto da origem, as condições que determinaram a forma como o novo Coronavírus entrou no mercado, não ganhou o destaque midiático necessário para se estabelecer os nexos causais estruturais: o vírus não entrou sozinho e inadvertidamente no mercado; que por sinal, se localiza na província de Hubei, uma das mais robustas da indústria avícola e da suinocultura intensiva chinesa, onde colônias de morcegos encontram refúgio e alimento desde que suas florestas naturais foram dizimadas, provocando uma interação explosiva entre essas espécies ${ }^{50}$.

Assim como não faltaram alertas sobre a real possibilidade de surgimento de uma pandemia do porte da COVID-19, que por fim realmente se estabeleceu; abundam alertas sobre futuros surtos pandêmicos, os quais inclusive podem ser originados na Amazônia. Sim, apesar da China ter sido o epicentro de muitas epidemias, a biodiversidade da floresta amazônica sofre da mesma pressão que sofre a também significativa biodiversidade das florestas subtropicais chinesas.

48 https://www.cartamaior.com.br/?/Editoria/Mae-Terra/O-desmatamento-e-a-monoculturadisseminam-a-COVID-19-e-outras-doencas/3/47488

49 https://agenciabrasil.ebc.com.br/internacional/noticia/2020-02/cientistas-descartam-quecoronavirus-tenha-origem-em-mercado-em-wuhan

50 https://diplomatique.org.br/sars-cov-2-suinocultura-intensiva-e-a-agricultura-industrializada/ 
Isso porque a floresta amazônica abriga uma biodiversidade fantástica e por conta disso, é um grande reservatório de Coronavírus. E é na recente intensificação do desmatamento na Amazônia, que emerge a combinação explosiva que pode ser o gatilho do processo que resulta no transbordamento de novos vírus ${ }^{51}$ para humanos.

$\mathrm{Na}$ contramão da proteção ambiental, em 2019 com o primeiro ano do regime Bolsonaro, o Brasil bateu o recorde de desmatamento na Amazônia dos últimos dez anos. Em meados de 2020 a mídia informa que a taxa de desmatamento na Amazônia avançou sem precedentes neste $a n o^{52}$, e que será o dobro do ano anterior ${ }^{53}$; apresentando, portanto, o risco de detonar um processo de savanização dessa floresta tropical, uma transformação capaz de gerar um desequilíbrio ambiental de dimensão monumental. Em entrevista, o climatologista Carlos Nobre alerta que há mais de 200 coronavírus que se hospedam em morcegos na Amazônia, e todo esse desequilíbrio ecossistêmico em larga escala, que ainda por cima ocorre em função da expansão agropecuária, representa um risco de transbordamento de micro-organismos presentes na biodiversidade amazônica para o ser humano, que não pode ser desprezado ${ }^{54}$.

Luiz Marques, professor da Unicamp, frisa que a Amazônia tem mesmo uma grande probabilidade de se tornar um importante foco das próximas pandemias zoonóticas ${ }^{55}$. A Amazônia, que já é um hotspot de epidemias não virais como a malária e a leishmaniose, ambas também correlacionadas à degradação ambiental, encontra-se no caminho do desastre sanitário com a atual escalada de devastação da floresta.

Não é possível prever o grau de letalidade das próximas pandemias. Mas não é possível ignorar que a Amazônia venha a ser o epicentro de futuras pandemias.

E esse é um motivo a mais para se preocupar com a sua proteção.

\section{Uma crise que encobre outra, maior e mais perigosa}

\footnotetext{
${ }^{51}$ http://www.ihu.unisinos.br/599132-a-proxima-pandemia-vira-do-brasil-destruindo-a-amazoniae-cada-vez-mais-provavel-um-novospillover?fbclid=IwAR0d2 5ERFOigocVGEE ATprOHiEa5PoCBx7Tzrl7K17eeifv2FNi2KM8Z0 $52 \mathrm{https}: / /$ congressoemfoco.uol.com.br/meio-ambiente/desmatamento-na-amazonia-dobra-em2020-e-bate-com-folga-o-recorde-de-2019/

53 https://noticias.uol.com.br/meio-ambiente/ultimasnoticias/redacao/2020/06/17/desmatamento-da-amazonia-deve-ser-50-maior-em-2020estimam-especialistas.htm

${ }^{54}$ https://www.oeco.org.br/reportagens/destruicao-da-amazonia-pode-transforma-la-emdeserto-e-desencadearpandemias/?utm source=wysija\&utm medium=email\&utm campaign=Newsletter+Diaria 55 http://www.ihu.unisinos.br/78-noticias/598974-serao-as-proximas-pandemias-gestadas-naamazonia-analise-de-luiz-marques
} 
Circulou nas mídias sociais em meados do primeiro semestre de 2020, uma imagem representando três ondas de crises sucessivas: primeiro, a crise da pandemia do Coronavírus, representada por uma pequena onda; depois a onda um pouco maior da crise econômica advinda das medidas restritivas à atividade econômica em função da quarentena; seguida por fim pela crise climática, essa sim, de proporções avassaladoras. Essa imagem apocalíptica deixa claro que se essa pandemia do novo Coronavírus já é uma crise de difícil enfrentamento, o caos climático atingirá cumulativamente outra escala deixando dúvidas se a civilização atual terá condições de enfrentar. Não é por acaso que abundam visões de um futuro apocalíptico frequentemente vinculado ao colapso climático, às vésperas do 'fim do mundo'56, 57 .

$\mathrm{E}$ não faltaram estudos científicos nem reportagens jornalísticas alertando para essa outra crise, que também está presente, mas ao contrário da crise sanitária, permanece invisível porque é difusa e se manifesta no largo prazo. A relação causal não é tão visível como a surpreendente existência de míseros 85 nanômetros, esse vírus invisível a olho nu - que é capaz de matar um paciente enfermo em $24 \mathrm{~h}$ para os casos mais graves da doença.

Corroborando a charge, a crise sanitária, social e econômica provocada pela COVID-19 "é apenas um prelúdio do que o planeta pode enfrentar se não responder à emergência climática", dizem Echecopar e Belmont em reportagem no El País ${ }^{58}$, em coro junto à comunidade científica ${ }^{59,60}$.

As mudanças climáticas, por si só, já se constituem como uma severa ameaça para a humanidade. A regulação climática global - outro serviço ecossistêmico provido em escala planetária pela natureza que foi interrompido , foi severamente comprometida em decorrência do lançamento excessivo de gases de efeito estufa na atmosfera. O mecanismo de regulação climática natural foi danificado, deixando-o anomalamente instável e extremado.

$E$ as interações entre as mudanças climáticas com pandemias só pioram o quadro: elas são um fator de agravo adicional ao contexto da degradação ambiental na emergência das epidemias. Porque elas não contribuem apenas com a desorganização do equilíbrio ecológico-climático global, comprometendo a integridade da biodiversidade e a resiliência ecológica dos ecossistemas, acarretando com isso o risco de surgimento de novas zoonoses, em função da degradação do estado de saúde dos animais mais sensíveis às mudanças climáticas. A novidade aqui é que elas também contribuem com a liberação de

\footnotetext{
${ }^{56} \mathrm{https}$ ://artebrasileiros.com.br/featured/ailton-krenak-livro-covid19-quarentena/

57 https://www.ecodebate.com.br/2020/06/10/a-sociedade-ainda-nao-percebeu-a-extensao-e-aurgencia-do-colapso-ecologico/

$58 \mathrm{https}$ ://brasil.elpais.com/opiniao/2020-06-14/como-seria-uma-recuperacao-verde-latinoamericana-e-com-justica-

social.html?fbclid=IwAR2zZ0dKieMGs19z8NUGs6SLEqLs8dOImsWwkjNli6pJec7hWAyb2bup3 GM

59 https://theintercept.com/2020/04/10/coronavirus-colapso-suicidio-climatico/

60 http://ricardoabramovay.com/licoes-da-pandemia-para-a-crise-climatica/
} 
vírus ancestrais que estiveram por milênios retidos nas geleiras e no pergelissolo (permafrost em inglês), agora em pleno processo de derretimento.

O derretimento das geleiras está expondo vastas regiões repletas de micróbios que estavam latentes, congelados especialmente no permafrost ${ }^{61}$ na Sibéria. O derretimento de uma geleira chinesa de quinze mil anos liberou 33 espécies de vírus, 28 deles ainda completamente desconhecidos pela ciência e com potencial para infectar seres humanos ${ }^{62}$.

É desconcertante testemunhar que no verão de 2020 a Sibéria tenha atingido temperaturas absurdamente anormais, e o Círculo Polar Ártico tenha sofrido com intensas queimadas. Todo o derretimento do gelo e da neve aumenta o fenômeno chamado 'espiral da morte', em função da supressão do 'efeito albedo', contribuindo com um aquecimento ainda maior, na medida que o branco do gelo que servia como espelho que refletia o calor solar devolvendo-o ao espaço, desaparece ${ }^{63}$.

É desconcertante testemunhar também que neste mesmo momento dos incêndios florestais no Ártico, uma nuvem gigante de gafanhotos devastou plantações de milho, cana-de-açúcar e mandioca no Paraguai, passou pela Argentina e deixou as autoridades sanitárias no Brasil em alerta, temendo a ocorrência de danos nas lavouras da região sul caso o flagelo da natureza desrespeitasse as fronteiras da nação. Suspeita-se que fenômenos dessa natureza estejam correlacionados às mudanças climáticas, em função do aumento da frequência de pragas de gafanhotos ${ }^{64}$.

Para impedir a crescente escalada de novas emergências sanitárias, é imperativo dentro do 'novo normal' pós-pandemia, que seja dada plena atenção às causas das zoonoses, e se confira prioridade máxima no combate ao desmatamento e a redução e fragmentação dos ecossistemas, a erosão da biodiversidade, o comércio ilegal de espécies selvagens, a invasão de espécies exóticas, a poluição, a falta de saneamento; e simultaneamente, as mudanças climáticas, para estancar a liberação de vírus ancestrais congelados.

Como duas crises interligadas, é importante perceber que a recomposição e revitalização de florestas, com recuperação de áreas degradadas, refaunação e ampliação de áreas legalmente protegidas pode assegurar um duplo benefício: ao mesmo tempo em que se reconstitui a barreira sanitária contra o transbordamento de micro-organismos, mantendo a saúde imunitária natural íntegra como um Serviço Ecossistêmico

\footnotetext{
${ }^{61}$ http://www.ihu.unisinos.br/597375-o-coronavirus-nos-obriga-a-reconsiderar-a-biodiversidadee-seu-papel-protetor

62 https://revistagalileu.globo.com/Ciencia/noticia/2020/01/28-novos-generos-de-virus-saoencontrados-em-gelo-de-15-mil-anos.html

$63 \mathrm{https}: / /$ www.oeco.org.br/noticias/comecou-a-temporada-de-queimadas-nasiberia/?utm source=wysija\&utm medium=email\&utm campaign=Newsletter+Diaria ${ }^{64} \mathrm{https}: / /$ www.redebrasilatual.com.br/ambiente/2020/06/nuvem-de-gafanhotos-pode-estarrelacionada-ao-aquecimento-global/
} 
reestabelecido; também se evita emissões de gases de efeito estufa provenientes dos incêndios nas florestas nativas. Assim se mantém o estoque de carbono na biomassa vegetal, recompondo o papel das florestas na estabilização climática, como um outro serviço ecossistêmico reestabelecido. Natureza, clima e saúde humana imbricados e simultaneamente protegidos.

Afinal, é precisamente aí - nas práticas predatórias da agropecuária industrial e seu processo de expansão ilimitada da fronteira do agronegócio capital-intensivo -, que estão as mudanças que precisam ocorrer: o 'novo normal' pós-pandemia - decisivamente engajado no combate das emergências pandêmicas e da alteração climática - deve se conjugar com outro modelo de produção agropecuária. Não é por acaso que a agroecologia desponta como uma promissora oportunidade ${ }^{65}$ revelada pelo novo Coronavírus, por se caracterizar como um modelo de produção agroindustrial que se entende como um sistema agroecológico, fundamentado no respeito aos fundamentos ecológicos.

Em todo caso, fica nítida a constatação de que com a pandemia do novo Coronavírus, o combate às mudanças climáticas ganha fôlego. Enfrentar as mudanças climáticas é uma forma estrutural de evitar futuras emergências sanitárias globais devido ao surgimento de novas zoonoses.

Não é possível prever o grau de danos advindos com o colapso climático. Mas não é possível ignorar que o colapso climático venha a ser 0 dinamizador do surgimento de futuras pandemias.

Essa é mais uma razão para se querer mudar o sistema, não o clima.

\section{Quando a Terra se aquietou: a quarentena e a ilusão da recuperação da Natureza}

É aqui que se descortina um lado positivo da pandemia, talvez o único, e que também apareceu rico de possibilidades de aprendizagens sobre as relações entre a pandemia e o meio ambiente, inspirando o pensar o 'novo normal' dessa pandemia em diante.

Nesta peculiar relação positiva da pandemia com a natureza, chamou a atenção um benéfico 'efeito colateral' da interrupção da economia, em função das medidas de quarentena e fechamento de atividades econômicas não essenciais: surgiram sinais de recuperação da qualidade ambiental, desde as aparições de animais circulando curiosos pelas ruas vazias de algumas cidades, até a redução de níveis de poluição atmosférica, passando pela diminuição da poluição sonora urbana. Com o ar mais limpo e o céu mais claro, pessoas testemunharam conseguir ver montanhas ao horizonte sempre escondidas por um céu poluído; e notícias dão conta de que menos automóveis

65 https://www.brasildefato.com.br/2020/04/01/artigo-a-agroecologia-em-tempos-de-covid-19 
circulando nas ruas e menos fábricas funcionando, satélites conseguiram detectar em várias regiões do planeta uma diminuição dos poluentes atmosféricos, no exato momento em que se encontravam em quarentena 66,67 , 68, 69. A Terra aquietou-se um pouco, quando a economia parou: a pandemia significou uma chance - inspiradora -, de recuperação da natureza.

As emissões globais de $\mathrm{CO}^{2}$ na atmosfera podem cair cerca de $4 \%$ em 2020 , em relação ao ano anterior, como efeito da pandemia. Embora isso soe como uma boa notícia advinda da emergência sanitária, há que se ressaltar duas coisas: primeiro, o gigantesco e cruel custo social e econômico da paralisia na economia global, tornando a desigualdade social ainda mais aguda, não nos permite falar de sustentabilidade.

Segundo, não nos iludamos: a queda na emissão de $\mathrm{CO}^{2}$ em função da pandemia não só é insuficiente para interromper o ritmo da mudança climática; como também teria que se manter sustentada daqui em diante. Contudo, como essa queda foi temporária como um breve suspiro, porque não ocorreram mudanças estruturais nos motores deste modelo econômico baseado na energia fóssil. A tendência segundo analistas é que se recupere o mesmo ritmo produtivista de antes da paralisação da economia, interrompido durante 0 efêmero período da quarentena.

Isso apesar da promessa de alguns países, particularmente da União Europeia, afirmarem ter o propósito de passar a orientar seus investimentos públicos na retomada da economia verde e descarbonizada. Com a criação do "Green Deal", prometem injetar mais de 460 bilhões de euros em iniciativas verdes. Lideranças do mundo econômico argumentam que para entrar no 'novo normal' será preciso aplicar o "Grande Reset", reconhecendo que é preciso repensar o sistema, o mundo não pode voltar ao mesmo normal de antes da pandemia ${ }^{70}$.

É importante lembrar aqui que o setor industrial e de serviços foram os responsáveis por esse efeito colateral positivo da quarentena, porque foram a economia secundária e terciária que tiveram suas atividades suspensas. Mesmo com uma ligeira queda na exploração mineral, a produção de commodities agroindustriais seguiram com suas práticas produtivas ininterruptamente ${ }^{71}$ durante o estado de pandemia.

\footnotetext{
${ }^{66}$ https://super.abril.com.br/ciencia/dia-da-terra-como-o-coronavirus-mudou-o-planeta/

67 https://istoe.com.br/ar-mais-puro-nos-paises-confinados-por-coronavirus/

$68 \mathrm{https://gizmodo.uol.com.br/mundo-coronavirus-poluicao-ano/}$

$69 \mathrm{https://piaui.folha.uol.com.br/pandemia-evita-um-bilhao-de-toneladas-de-carbono-na-}$ atmosfera/?utm source=pushnews\&utm medium=pushnotification

70 https://noticias.ambientebrasil.com.br/clipping/2020/06/18/160622-a-pandemia-docoronavirus-pode-ser-uma-chance-ao-verde.html

${ }^{71}$ https://economia.uol.com.br/noticias/estadao-conteudo/2020/05/23/agronegocio-sustenta-ocrescimento-das-exportacoes-durante-crise-global.htm
} 
O setor produtivo primário não contribuiu com esse efeito positivo do aquietamento do planeta, ao contrário: manteve seu modelo produtivo predatório e ecocida firmemente empenhado na abertura da fronteira do agronegócio capital-intensivo. Nesse contexto fica a dúvida de até que ponto as promessas de uma retomada verde da economia envolverão a revisão do modelo hegemônico da produção destrutiva na economia primária. Sua responsabilidade deve ser vivamente cobrada, afinal de contas, é o setor da economia que está na base do processo de conversão de ecossistemas florestais nativos em pastagens e monoculturas de grãos dependentes da aspersão de agrotóxicos, avançando com a grilagem de terras, o desmatamento ilegal e as queimadas como modus operandi clássico da produção destrutiva; que resulta no aniquilamento da biodiversidade, na emissão de gases de efeito estufa e na emergência de epidemias.

Mas apesar dos pesares, uma coisa é certa: com o reconhecimento de que a crise climática somada à erosão da biodiversidade é um fator agravante no cenário de emergência de novos surtos pandêmicos; acrescido do reconhecimento de que 0 acionamento desse freio de emergência que proporcionou um breve descanso para Gaia, ocorreu o reconhecimento de que a Natureza pôde se recompor em alguns lugares, reforçando o desejo de mudança da relação do ser humano com a natureza, o que representa uma preciosa aprendizagem adquirida no diário da quarentena. Se o ritmo estava acelerado demais, de alguma forma terá que diminuir a velocidade.

\section{Ecocídio e a radicalização do antiecologismo no regime Bolsonaro}

Há exatamente 50 anos atrás, no início dos anos 70, travou-se uma batalha épica que demarcaria o futuro da humanidade. De um lado, as forças economicistas, afirmando que, para eliminar a pobreza, o Desenvolvimentismo seria a orientação a seguir, estimulado pelas Nações Unidas que instituíram os anos 60 como a década do Desenvolvimento. Do outro lado, estavam as forças sustentabilistas, surgindo timidamente no cenário dos primeiros problemas ambientais advindos do esforço economicista que desde o início se viu como um sistema independente do sistema natural.

Em 1972, é publicado um relatório científico que fez tremer as bases do então mundo desenvolvido, e frustrou os países que ambicionaram seguir o caminho do desenvolvimento. Intitulado apropriadamente como 'Limites do Crescimento', ousou declarar que para evitar uma crise ambiental vindoura, decorrente do próprio estilo de desenvolvimento economicista, seria necessário frear o crescimento econômico. Seria o equivalente a enterrar a ideia desenvolvimentista justamente quando ela passa a ganhar adesão incondicional mundialmente. De uma forma ou outra, havia que paralisar a insana marcha economicista, que apontada pelos 'profetas do apocalipse', nos levaria ao desastre ambiental. 
A batalha entre o desenvolvimentismo economicista e a sustentabilidade perdurou por duas décadas. Foram vinte anos de uma relação de poder tencionada, até que em 1992, durante a Conferência do Rio, estabeleceu-se um pacto e fez-se uma escolha civilizatória para evitar a catástrofe: um desenvolvimentismo orientado pelos critérios da sustentabilidade. $O$ Desenvolvimento Sustentável. A fórmula reside no justo equilíbrio dessa tensão de forças antagônicas, o que seria alcançado por meio de parâmetros éticos, como os elencados pela Carta da Terra, mas seria alcançado também por meio do estabelecimento de institucionalidades ambientais, por estatutos jurídicos e por políticas públicas definidoras de regras e limites da ação humana.

Note-se que essa fórmula para frear a desmesura da economia foi aceita em tempos neoliberais, a doutrina econômica que advoga a não interferência na economia, posto que as regras de mercado naturalmente guiaram o comportamento econômico na direção correta da sustentabilidade. Exceção à regra, a pauta ambiental atreveu-se a domesticar o neoliberalismo. Só que não.

Desde a Rio 92, quando acreditávamos finalmente ter entrado no caminho da sustentabilidade, na verdade, adentramos (desavisadamente) na versão capitalista da sustentabilidade: aquela que nos faz crer que bastaria adequar nosso padrão de produção e consumo ao constrangimento ambiental que tudo seria resolvido, porque de um lado, havia a expectativa cornucopiana do desenvolvimento das tecnologias limpas para uma economia verde e circular; e do outro lado, conectando a produção com o consumo, havia a expectativa do consumidor verde representar a orientação necessária ao mercado por meio de suas escolhas.

Contudo, a fórmula capitalista da sustentabilidade, que preceitua a incorporação da gestão ambiental privada e da produção mais limpa no âmbito produtivo, associada à internalização de comportamentos ecologicamente corretos e de escolhas ecológicas na esfera do consumo, não passou de um embuste cosmético. Isso porque a proposta de mudança nos padrões de produção (linear para circular) e consumo (desmesurado para consciente), deixa de fora do enquadramento o elemento mais importante, por ser 0 estrutural: o modelo econômico capitalista. É a representação clássica da 'modernização conservadora': mudar para não alterar. Não alterando a dimensão estrutural, o modelo segue o curso da sua lógica, onde os imperativos do lucro, da propriedade privada, da competição, da meritocracia individualista, do consumismo, do desperdício da produção destrutiva, da financeirização da Vida e da liberdade econômica (desregulação do Estado), seguem inabalados.

Infelizmente os indicadores de sustentabilidade evidenciam que a tendência é desanimadora. A cada ano, aumenta-se a dívida ecológica com o planeta, e a pegada ambiental se aprofunda. Tudo indica que a janela de oportunidade de mitigar a crise ambiental que se avizinhava no horizonte humano no início da década de 90 foi perdida, e a crise ambiental se instalou. 
O início da primeira década do século 21 testemunhou subitamente o recuo da conciliação entre o mercado e a natureza, entre a economia e a ecologia. O pacto foi desfeito e assim se deu o surgimento do antiecologismo, demarcando uma nova era nas relações do poder antagônico e desigual entre o desenvolvimento e a sustentabilidade, pondo um fim à era da bonança ambiental, onde os avanços institucionais na defesa ambiental representaram uma conquista civilizatória de direitos ${ }^{72}$. O frágil equilíbrio no mundo politicamente correto entre 0 desenvolvimentismo economicista e a proteção ambiental foi rompido, e pesou, sem mi-mi-mi, a favor da franca e escancarada exploração predatória da natureza, agora destituída de quaisquer 'entraves' que pudessem atrapalhar o crescimento da economia de livre-mercado.

São justamente os mecanismos institucionais de proteção ambiental sob tutela constitucional do Estado brasileiro, que asseguram minimamente que o desenvolvimentismo esteja de fato orientado pela sustentabilidade, que estão na mira e sob ataque do antiecologismo.

Se antes, na fase da consolidação do ambientalismo na cultura institucional brasileira, as coisas já não estavam bem, com a emergência do antiecologismo, piorou. Não bastasse a devastação ambiental nos ecossistemas, no mundo da vida; agora existe também uma devastação institucional, com um tsunami de retrocessos e desmonte dos instrumentos públicos de política e gestão ambiental.

Ao longo da instalação do processo da crise ambiental, a emergência climática com suas várias faces (especialmente relacionadas a questões hídricas) foi sua primeira manifestação; e em seguida expressou-se com a emergência sanitária, que teve no COVID-19 o atingimento de uma situaçãolimite para um conjunto de epidemias resultantes de problemas com degradação ambiental que o antecederam.

E para nosso desespero, no exato momento histórico em que o estado de emergência ambiental começa a se instalar, emerge o signo do antiecologismo dominando o campo político, tendo no regime Bolsonaro a inauguração de uma nova fase, marcada pela radicalização vertiginosa do desmonte ambiental, a ponto de emergir um profundo ecocídio para acompanhar a necropolítica da desigualdade social.

De modo trágico, é exatamente quando o pensar o 'novo normal' do mundo pós-COVID-19 clama por um efetivo enfrentamento da degradação ambiental - para simultaneamente combater a origem de futuras pandemias e os efeitos do colapso climático -, o Brasil, país mega biodiverso e responsável pelo destino da floresta amazônica, elimina totalmente a possibilidade de assumir essa atribuição.

72 Para uma visão detalhada do antiecologismo ver Layrargues (2017, 2018a, 2018b, 2020). 
O presidente da república protagoniza, com seus ministros do meio ambiente e da agricultura (conhecida no exterior como a 'senhora desmatamento' de Bolsonaro ${ }^{73}$ ), o projeto político do derradeiro desmonte e retrocesso ambiental, para eliminar todos os instrumentos públicos de política e gestão ambiental federal, desligando então os mecanismos de comando e controle na fiscalização e combate ao crime ambiental. Fez recuar a frente de defesa ambiental institucional, cujos servidores públicos federais da carreira ambiental passaram não só a ficar impedidos de deter a boiada enquanto ela avança mata adentro, mas também interditados de denunciar que a boiada está passando e sem controle.

Como então pode o Estado brasileiro dar uma resposta à altura do desafio do colapso ambiental, se ele próprio abre mão de contar com os mecanismos e ferramentas criadas exatamente para essa finalidade? Como gerir a crise ambiental sem os instrumentos de política e gestão ambiental que antes tinham condições de deter a desmesura da expansão descontrolada da fronteira agropecuária?

A pandemia irrompe exatamente nesse contexto da radicalização antiecologista no Brasil, que têm se valido como característica predominante o uso massivo dos 'aparelhos repressores de Estado' para vigiar e punir os servidores públicos federais da carreira ambiental enquanto esvazia a pasta ambiental de suas funções gerenciais, normativas, regulatórias e educadoras, provocando um 'apagão' gerencial na área ambiental. Como o Estado poderia continuar cumprindo com sua atribuição de combate do colapso climático quando ele próprio passou a ser negacionista climático; e uma das primeiras medidas de governo Bolsonaro foi justamente de fechar a Secretaria de Mudança do Clima e Florestas do Ministério do Meio Ambiente ${ }^{74}$ ?

No limite, o governo federal parece não ter poupado esforços que resultassem na paralização completa da fiscalização ambiental, como a militarização dos órgãos federais com policiais e oficiais militares ocupando cargos estratégicos ${ }^{75}, 76$; como a transferência de competências do IBAMA para o Núcleo de Conciliação Ambiental ${ }^{77}$; como a implantação da 'lei da mordaça' dentro dos órgãos ambientais federais ${ }^{78}$; como a interferência das Forças

\footnotetext{
$73 \mathrm{https}: / /$ deolhonosruralistas.com.br/2020/05/29/le-monde-faz-perfil-de-tereza-cristina-e-achama-de-senhora-desmatamento-debolsonaro/?fbclid=IwAR2uTaUfg7WP4kILG5x xJNJQBzLvhiJ32nYT7K90KuLRG-x9Y6CFi-9jak

${ }^{74} \mathrm{https}$ ://oglobo.globo.com/sociedade/sustentabilidade/governo-acaba-com-secretariadedicada-mudancas-climaticas-gera-temor-entre-cientistas-23352452

75 https://www.nexojornal.com.br/expresso/2019/04/28/As-crises-e-amilitariza\%C3\%A7\%C3\%A3o-do-Minist\%C3\%A9rio-do-Meio-Ambiente

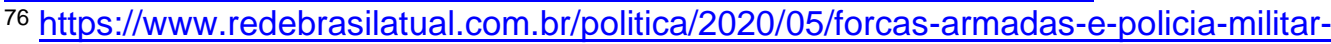
aumentam-controle-sobre-orgao-ambientais/

77 https://brasil.elpais.com/brasil/2019/04/11/politica/1555009346 229285.html

$78 \mathrm{https}: / /$ politica.estadao.com.br/noticias/geral,ministerio-do-meio-ambiente-impoe-lei-damordaca-a-ibama-e-icmbio, 70002753849
} 
Armadas sobre o IBAMA na operação de Garantia da Lei e da Ordem na Amazônia ${ }^{79}$; como a exoneração dos chefes de fiscalização do IBAMA como represália à operação de combate ao garimpo em Terra Indígena ${ }^{80}$; como a escandalosa proibição (ilegal) de destruição de maquinário apreendido em autos de infração por ocasião de campanhas de fiscalização contra o crime ambiental em áreas remotas.

Tudo que implique no fim daquela 'indústria de multas' a qual Bolsonaro fazia alusão durante o período da campanha eleitoral, que prometera acabar. $\mathrm{E}$ enquanto os alertas de desmatamento aumentavam sucessivamente ao longo dos anos de 2019 e 2020, o IBAMA passou a aplicar o menor número de multas desde os últimos 21 anos $^{81}$; e a grilagem de terras atingiu seu auge, com doze dos cinquenta milhões de hectares de florestas públicas na Amazônia invadidas ${ }^{82}$. Até então, Bolsonaro parece ter conseguido cumprir a promessa antiecologista de neutralizar o papel institucional do IBAMA na fiscalização ambiental e aplicação de multas para a boiada não passar.

Note-se ainda sob o signo antiecologista, logo no início do governo Bolsonaro, o atributo democrático central da política ambiental brasileira também foi suprimido, com o desmonte do CONAMA, quando se restringiu a participação da sociedade civil organizada representativa do universo das organizações ambientalistas não-governamentais ${ }^{83}$, neutralizando assim, a voz dos 'ativistas ambientais'. Junto desse movimento antidemocrático, o governo deu outro passo na direção da censura, ao centralizar no MMA todas as informações da gestão ambiental de suas autarquias IBAMA e ICMBio, que perderam sua autonomia ${ }^{84}$; e ao negar-se a responder solicitações de informações pela mídia ${ }^{85}$ : nada menos que oito em cada dez reportagens sobre a política ambiental brasileira terminaram com uma nota final, esclarecendo que até a finalização daquela matéria a assessoria de comunicação do MMA não havia se manifestado sobre o assunto solicitado. O antiecologismo na

\footnotetext{
79 https://noticias.uol.com.br/meio-ambiente/ultimas-noticias/redacao/2020/06/28/forcasarmadas-gastam-milhoes-atrapalhando-a-fiscalizacao-naamazonia.htm?fbclid=IwAR1v0rPqcNXaP DidhvlZr2dcei29ghCUaG pG506VC1Kgno4A1zhPJ WHL4

${ }^{80}$ https://www1.folha.uol.com.br/ambiente/2020/04/ibama-exonera-chefes-de-fiscalizacao-aposoperacao-contra-garimpo.shtml

81 https://www.poder360.com.br/governo/ibama-aplica-o-menor-numero-de-multas-em-21-anos$\mathrm{m} /$

82 https://www.oeco.org.br/noticias/grileiros-ja-tomaram-quase-12-milhoes-de-hectares-deflorestas-publicas-naamazonia/?utm source=wysija\&utm medium=email\&utm campaign=Newsletter+Diaria $83 \mathrm{https}: / /$ www1.folha.uol.com.br/ambiente/2019/05/salles-corta-77-de-conselho-ambientalretira-icmbio-e-fara-sorteio-de-vagas.shtml

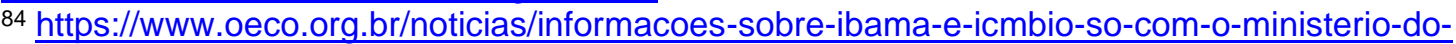
meio-ambiente/

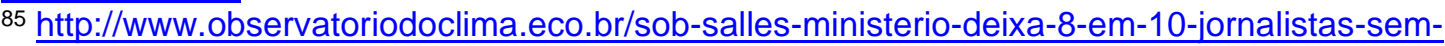
respostal
}

Revbea, São Paulo, V. 15, № 4: 01-30, 2020. 
versão Bolsonaro não mede esforços para dissimular o desmonte. Procura não chamar a atenção.

Contudo, o antiecologismo é uma variável que entra na equação desse imbricamento de crises que não pode ser menosprezada, posto que o desmonte ambiental ora em curso compromete exatamente 0 aparato institucional da máquina pública que detinha as prerrogativas legais e administrativas para gerir o estado de emergência ambiental a fim de mitigar concomitantemente o colapso climático e o surgimento de novas pandemias, particularmente na região amazônica. Afinal, como controlar o colapso ambiental a partir do território nacional, com o sistema institucional de defesa ambiental colapsado pelo antiecologismo no regime Bolsonaro?

\section{O ‘novo normal’ e o pensar uma Educação Ambiental Ecopolítica}

Em outra ocasião (LAYRARGUES, 2020), partindo do pressuposto que a Educação Ambiental foi cooptada pela forma cultural capitalista de pensar e fazer uma Educação Ambiental, e assim se tornou conservadora e instrumental ao sistema; e considerando o entrecruzamento da conjuntura global do emergente colapso climático com a conjuntura ecopolítica nacional demarcada pelo vertiginoso retrocesso ambiental no regime Bolsonaro, declaradamente pautado pelo signo do antiecologismo e pelo negacionismo climático -, levantamos o questionamento se a Educação Ambiental seria impactada por essa nova e desafiadora realidade ecopolítica.

Essa impactante conjuntura seria capaz de provocar na Educação Ambiental alguma reação no sentido do desenvolvimento de um esforço programático de intensificação da formação cidadã, constituindo um 'sujeito ecopolítico' dotado de conhecimentos, competências e habilidades para agir politicamente na luta ambiental democrática contra as políticas públicas ecocidas implantadas pelo regime antiecologista de Bolsonaro? Ou o campo da Educação Ambiental se manteria indiferente à nova conjuntura, circunscritos à anacrônica e inócua fórmula neoliberal de se pensar e fazer Educação Ambiental, permanecendo estagnada na prática de seguir conformando os educandos em dóceis e obedientes sujeitos ecológicos? A oportunidade da mudança para a formação de um sujeito irreverentemente ecopolítico seria desperdiçada?

A importância dessa questão recai sobre a premissa de que o modelo conservador de Educação Ambiental atualmente predominante no Brasil não tem condições de lidar com esta nova realidade (LAYRARGUES, 2018b); ele é ineficaz, porque não está dentro do seu enquadramento programático nem entre as competências esperadas, o desenvolvimento das qualidades necessárias para o efetivo enfrentamento da emergência dessas múltiplas e inter-relacionadas crises: o modelo conservador de Educação Ambiental não trabalha com os pressupostos da Ecologia Política para a correta fundamentação conceitual dos fenômenos e mecanismos dinamizadores da 
degradação ambiental e da crise ambiental, e tampouco se dispõe a formar sujeitos políticos que saibam se expressar para além da esfera doméstica e do círculo de consumo, diferentemente da domesticação e dócil subserviência à obediência e ordem.

Essa Educação Ambiental conservadora e subserviente ao Capital é instrumental e funcional ao sistema, porque ela não se dispõe a influir na dimensão estrutural da crise ambiental com a energia da indignação contra uma situação limite que foi ultrapassada. Conformado, adotando o realismo pragmático, esse modelo está em descompasso com o tempo presente, que demanda outra abordagem: resolutamente inconformada, mobilizada e comovida pelo extraordinário senso de urgência. Trata-se de trazer a percepção da urgência no lugar do conformismo. A indignação no lugar da indiferença.

É neste horizonte, de ocorrência de mais um drama socioambiental de dimensões apocalípticas - o surgimento de uma severa pandemia com implicações sociais e econômicas devastadoras, causada pelo absurdo nível de desequilíbrio ambiental que se chegou em escala global -, que o questionamento acima adquire ainda mais importância. A pandemia reforça a gravidade e atualiza o senso de urgência da crise ambiental, e isso representa uma provocação a mais pela ressignificação paradigmática da Educação Ambiental como reação do campo à nova conjuntura.

Emergência! Todo esse custo ambiental apenas para passar a boiada? Emergência! Não apenas no sentido de algo que eclode, emerge e irrompe na superfície. Mas emergência, também no sentido de uma situação grave, crítica, limite! É no estado de urgência que se aciona a saída de emergência!

No final das contas, depois dos dados epidêmicos da expansão da contaminação que cotidianamente foram publicizados na mídia; as atenções não sem razão estiveram predominantemente focadas nas consequências da pandemia: as crises social e econômica. Com isso, acabou-se sombreando o debate que infelizmente veio a se tornar marginal, apesar de estrutural: as causas que originaram essa pandemia. O sombreamento dessa imperativa reflexão impediu a disseminação da reflexão dos fatores que culminaram nessa situação, para que na agenda do combate à pandemia, as causas estruturais do surgimento delas sejam preventivamente desativadas. Assim, avaliamos que nos primeiros seis meses de um mundo paralisado pelo COVID-19, o debate midiático sobre as causas (ambientais) da pandemia poderia ter sido mais ousado. Tudo indica que se desperdiçou uma oportunidade ímpar de aprendizagem socioambiental a partir da vivência na crise sanitária; inspirando o estabelecimento do 'novo normal' sustentado pelo clamor do reestabelecimento da saúde ambiental planetária como um valor prioritário a orientar decisões políticas.

O que precisa ficar claro é que a compreensão das causas que originaram a pandemia do COVID-19 não é um mero preciosismo acadêmico, 
ao contrário; traz profundas implicações políticas, uma vez que é a partir desse conhecimento que será possível implementar políticas públicas elaboradas com o propósito de combater a emergência de futuras pandemias. As evidências científicas apontam para uma forte recorrência e perigosa escalada de surtos zoonóticos, tendo como origem exatamente os fatores ambientais. Caso não haja um enfrentamento político preventivo e decisivo sobre o controle das causas de raiz ambiental da pandemia, as previsões dos especialistas de que 0 novo Coronavírus seria apenas o prenúncio de um futuro pontuado por surtos epidêmicos poderão se confirmar ${ }^{86}$. Eis um argumento a mais na lista a favor da defesa da qualidade ambiental. O COVID-19 deu uma razão importante para proteger a natureza. Como elos imbricados na teia da complexidade, humanos são protegidos na mesma medida que protegem a natureza, a saúde humana é dependente da saúde ambiental.

Como atributo básico a se caracterizar como "novo normal" no mundo pós-pandêmico, é a compreensão de que a qualidade ambiental da biosfera está visivelmente mostrando sinais de colapso, está demonstrando experimentar o limite de esgotamento das funções ecossistêmicas prestadas como "serviços ambientais".

Neste novo normal que traz a marca de origem de uma violenta crise sanitária-social-econômica, a degradação ambiental, alimentada ainda pelas mudanças climáticas, dali em diante já não é mais suficiente estimular a "sustentabilidade" exclusivamente na esfera individual e no âmbito privado do consumo. Essa fórmula não foi suficiente para se evitar chegar à presente situação e se esgotou; o tempo pós-pandêmico necessita da superação desse modelo para sair da fórmula do 'sujeito ecológico' despolitizado, que não incorporou no seu repertório militante da causa ambiental, o controle social das políticas públicas de meio ambiente. O novo normal convoca o surgimento do sujeito ecopolítico, incondicionalmente determinado a combater diretamente a degradação ambiental e reverter o jogo a favor da revitalização das áreas naturais e protegidas, cientes de que para isso, é imperativo reconstruir a máquina pública constitucionalmente responsável pela gestão ambiental, dando especial atenção à importância das políticas públicas ambientais como organizadoras da repactuação do desenvolvimentismo com a sustentabilidade. Neste tempo de quarentena contra a onda de contaminação da COVID-19, é tempo de compreender os motivos que nos trouxeram a essa situação de confinamento social. É tempo de compreensão dos limites, limites que foram ultrapassados, mas até então tolerados.

Em 30 de janeiro de 2020 a OMS declarou que o surto do novo Coronavírus constituiria uma Emergência de Saúde Pública de Importância

\footnotetext{
${ }^{86}$ https://www.code-animal.com/pourquoi-le-coronavirus-ne-sera-certainement-pas-la-dernierepandemie-mondiale/
} 
Internacional ${ }^{87}$, caracterizado como sendo o nível de alerta global mais alto da instituição. E em 11 de março, em função da ampla distribuição do novo Coronavírus pelo planeta, a OMS decreta o estado de pandemia do COVID-19. Estas decisões demarcaram situações-limite e visaram estabelecer uma resposta global rápida, coordenada e enfática para deter o avanço do vírus. Trata-se de um protocolo para emergências, situações extraordinárias de alto risco para a saúde da população humana, que estabelece procedimentospadrão a serem seguidos. O alerta da situação-limite sinalizou claramente para o risco do colapso do sistema de saúde em função do alto número de pessoas contaminadas que necessitariam de suporte médico intensivo. Ante a tenebrosa possibilidade do risco de colapso no sistema de saúde, a estratégia principal recaiu no isolamento social a fim de diminuir a taxa de propagação do vírus e "achatar" a curva de contaminação, possibilitando que o sistema de saúde pudesse receber pacientes sem operar acima da sua capacidade máxima.

São protocolos da envergadura desta emergência sanitária da OMS que precisam ser efetivados para conter o colapso do sistema climático, apesar de amplamente reconhecido como uma situação-limite que não pode ser ultrapassada. O alerta sanitário da COVID-19 foi um sinal muito claro de que chegou a hora de se levar a sério a elaboração de políticas públicas de conter a devastação de ecossistemas preservados.

Desmatamento. Queimadas. Tráfico de animais silvestres. Petróleo. Agrotóxicos. Um modelo produtivo pautado pelo interesse da reprodução do Capital. Uma lógica econômica fundamentada no Mercado como regulador social. Um projeto desenvolvimentista ecocida orientado pela necropolítica. São muitos os limites ultrapassados, são muitos e de várias ordens os abusos cometidos pela atual ordem mundial capitalista. E por causa desses limites que foram ultrapassados que surgiram toda essa ordem de crises e colapsos.

Luiz Marques alerta que o colapso ambiental não é um evento e sim um processo ${ }^{88}$, e que esse processo já está em curso, não é uma remota eventualidade futura. $O$ professor afirma ainda ${ }^{89}$, que 0 ano de 2020 será lembrado como o ano em que uma epidemia gerou uma profunda e marcante ruptura no funcionamento da sociedade contemporânea, cuja recuperação ainda é incerta. Isso porque se trata de uma conjunção de três crises estruturais que se reforçam reciprocamente: a emergência climática, a erosão da biodiversidade e o adoecimento dos organismos, intoxicados pela indústria química. Para o autor, estamos vivendo os anos mais importantes da história

\footnotetext{
${ }^{87}$ https://www.paho.org/bra/index.php?option=com content\&view=article\&id=6101:covid19\&lte $\mathrm{mid}=875$

$88 \mathrm{http}: / /$ revistarosa.com/1/o-colapso-socioambiental-nao-e-umevento?fbclid=IwAR0KHIYOR9RsvMCh11vLwAh8KzmIMsY2UiuWhA2IY5gO1460Kwpi1F0D3Y $\underline{8}$

$\frac{8}{89}$ https://www.unicamp.br/unicamp/noticias/2020/05/05/pandemia-incide-no-ano-maisimportante-da-historia-da-humanidade-serao-proximas
} 
moderna, capazes de definir um futuro de sucesso ou colapso civilizatório. $O$ ano de 2020 é o ano apontado por especialistas das ciências climáticas como a data limite para se atingir o pico das emissões de gases de efeito estufa, sob risco de inviabilizar as metas do Acordo de Paris.

É importante que se crie expectativas de qual pode ser a contribuição da Educação Ambiental para superar os tempos da pandemia. A contribuição da Educação Ambiental para a construção do 'novo normal' pode ser uma tarefa civilizatória, por ser uma área social do conhecimento que tem como atribuições natas toda a problematização pedagógica daquilo que diz respeito às interações humanas e o meio ambiente. Déborah Danowski, filósofa professora da PUC-SP, chama atenção primeiro que a humanidade está longe de perceber a tragédia advinda com o colapso ambiental em curso, e segundo, que a mídia não colaborou como poderia para reverter essa percepção distorcida da realidade ${ }^{90}$.

A contribuição da Educação Ambiental em tempos de pandemia pode ser oferecida na imaginação do mundo de amanhã, o 'retorno' à uma nova normalidade, mas com os ingredientes próprios que dão o sabor do saber ambiental; onde esteja clara a noção de Hybris, os limites naturais que no mundo grego pré-socrático jamais poderiam ser ultrapassados, tendo na mitologia toda representação pedagógica para essa importante aprendizagem pela vida na relação humana com a natureza; onde esteja clara a leitura ecopolítica de relações causais e complexas que envolvem as relações humanas com a natureza e que seja de ampla compreensão o que está na origem da degradação ambiental, das mudanças climáticas, das pandemias; que seja de ampla compreensão o que significa a política pública antiecologista, demarcando 0 retrocesso ambiental, o desmonte das instituições públicas de defesa ambiental, a falência da legislação ambiental, o colapso da fiscalização ambiental e a complacência com a impunidade do crime ambiental.

Mas não basta, nesta tarefa civilizatória de reconduzir o destino da humanidade por uma rota saudável e sustentável, apenas assimilar e ampliar o repertório de conhecimentos sobre as faces e interfaces da crise ambiental, tampouco reforçar o valor da importância dos limites ecológicos não serem ultrapassados. Para o campo da Educação Ambiental, não se trata apenas de incorporar novos temas para debate pedagógico. Além de conteúdos programáticos, é preciso também que haja uma nova atitude do cidadão, não apenas 'ecológico', mas ecopolítico, que supere a importante mas desproporcional contribuição individual para a sustentabilidade e se engaje na luta política, que integre movimentos políticos, faça parte da esfera pública, que se engaje na causa, que seja movido pela ambição de interferir. Não basta

\footnotetext{
$90 \mathrm{https}$ ://apublica.org/2020/06/nao-tem-mais-mundo-pra-todo-mundo-diz-deborahdanowski/?fbclid=IwAR3esDf9SRdDccKrH3gg-

Tyr6Y0CsUzDxyyQf9 MEOzQJJDliSNjEM HF3A\#.Xt PtaFCBzc.facebook
}

Revbea, São Paulo, V. 15, № 4: 01-30, 2020.

revista brasileira

educação ambiental 
ampliar o conhecimento do problema, ampliar a compreensão da correlação entre a pandemia e a degradação ambiental, é imperativo também formar capacidades e atitudes de enfrentamento coerente à urgência do desafio.

\section{Referências}

CONTINI, C. et al. The novel zoonotic COVID-19 pandemic: an expected global health concern. J. Infect. Dev. Ctries, 14(3):254-264. 2020.

DAILY, G.C. What are ecosystem services? In: DAILY, G.C. (Org.) Nature's Services: societal dependence on Natural Ecosystems. Washington: Island Press. p. 1-10. 1997.

EVANS, T. et al. Links between ecological integrity, emerging infectious diseases originating from wildlife, and other aspects of human health. New York: Wildlife Conservation Society. 2020.

LAYRARGUES, P.P. Antiecologismo no Brasil: reflexões ecopolíticas sobre o modelo do desenvolvimentismo-extrativista-predatório e a desregulação ambiental pública. In: OLIVEIRA, M.M.D.; MENDES, M.; HANSEL, C.M.; DAMIANI, S. (Org): Cidadania, Meio Ambiente e Sustentabilidade. Caxias do Sul: EDUCS, p.325-356. 2017.

LAYRARGUES, P.P. Quando os ecologistas incomodam: a desregulação ambiental pública no Brasil sob o signo do antiecologismo. Revista Pesquisa em Políticas Públicas, n. 12, pp. 1-30. 2018 a.

LAYRARGUES, P.P. Subserviência ao capital: educação ambiental sob o signo do antiecologismo. Pesquisa em Educação Ambiental, 13(1):28-47. 2018 b.

LAYRARGUES, P.P. Manifesto por uma Educação Ambiental indisciplinada. Ensino, Saúde e Ambiente. Número Especial, p. 44-87, Junho. 2020.

MÉSZÁROS, I. Produção destrutiva e Estado capitalista. São Paulo: Ensaio, 1989.

NAYLOR, R.L., EHRLICH, P.R. Natural pest control services and agriculture. In: DAILY, G.C. (Org.) Nature's Services: societal dependence on Natural Ecosystems. Washington: Island Press. p. 151-174. 1997.

QUAMMEN, D. Spillover: Animal Infections and the Next Human Pandemic. New York. W.W. Norton \& Company. 2012.

SOFFIATI, A. Depois do princípio e antes do fim: meio ambiente e poesia. Campos dos Goytacazes: Damadá. 1990.

UNEP. UNEP Frontiers 2016 Report: Emerging Issues of Environmental Concern. Nairobi: United Nations Environment Programme. 2016.

WALLACE, R. Pandemia e Agronegócio: doenças infecciosas, capitalismo e ciência. São Paulo: Elefante. 2020. 